\title{
A Geomagnetic Reversal in the Latest Brunhes Epoch Discovered at Shibutami, Japan
}

\author{
Hidefumi TANAKA* and Koichi TaChIBANA** \\ *Department of Applied Physics, Tokyo Institute of Technology, \\ Meguro-ku, Tokyo, Japan \\ ${ }^{* *}$ Faculty of Education, Iwate University, Iwate, Japan
}

(Received May 17, 1980; Revised March 15, 1981)

The discovery of a geomagnetic reversal from the Shibutami welded tuff, Iwate Prefecture (about $500 \mathrm{~km}$ north of Tokyo), was already reported by TACHIBANA (1977), in which it was concluded that this reversal may be related to the Laschamp event of about 20,000-30,000 years B.P. (BONHOMMET and Z̈̈HRINGER, 1969) or the Lake Mungo geomagnetic excursion around 30,000 years B.P. (BARBETTI and MCELHINNY, 1976). In this note, an additional paleomagnetic study of this reversal is reported.

The origin of these welded tuff is not yet fully clarified, but it is generally thought that the pyroclastic flow was originated from a region west of Shibutami and deposited in a short time span, and the distribution of the welded tuff is shown in a geological map of Fig. 1. The age of the formation was concluded to be about 30,000 years B.P. This ${ }^{14} \mathrm{C}$ age was derived from materials in adjacent layers, but the time difference is small judging from various geological considerations (TACHIBANA, 1977). One of the most important geological evidences is shown in Fig. 2. Layer of the welded tuff (E) is sandwiched between sand and gravel beds (F, D), but the upper (F) and the lower (D) sand and gravel beds are considered to be of the same origin, so the welded tuff between beds must have formed at almost the same time as these beds. Two radiocarbon ages of $30,780 \pm 2,170$ and 29,630 $\pm 2,130$ years B.P. were determined from the carbonated woods contained in the sand and gravel bed (TACHIBANA, 1977). The age of the welded tuff therefore is about 30,000 years B.P. As this age was not determined directly from the welded tuff layer, further investigation is needed to precisely date the particular layer.

Five to eight cores were sampled by an engine drill at each of the four sites located several kilometers apart from each other indicated in Fig. 1. Thermomagnetic analysis was carried out for a bulk sample taken from the second site (SI 2) using a magnetic balance with a vacuum of $10^{-5}$ Torr and a magnetic field of $5 \mathrm{kOe}$. A single Curie temperature $\left(T_{\mathrm{C}}\right)$ of $534^{\circ} \mathrm{C}$ was obtained. This indicates that the magnetic minerals contained in this sample are almost pure magnetite, so that the possibility of self-reversal of the NRM is minimal with this sample.

Two pilot specimens were demagnetized progressively in the alternating field (A.F.) up to a peak field of $1,600 \mathrm{Oe}$. These demagnetization curves showed an increase in NRM intensity of 10 to $50 \%$ around the peak field of $150 \mathrm{Oe}$. This kind of behavior is often observed in samples with reversed NRM, and usually interpreted as the effect of a 


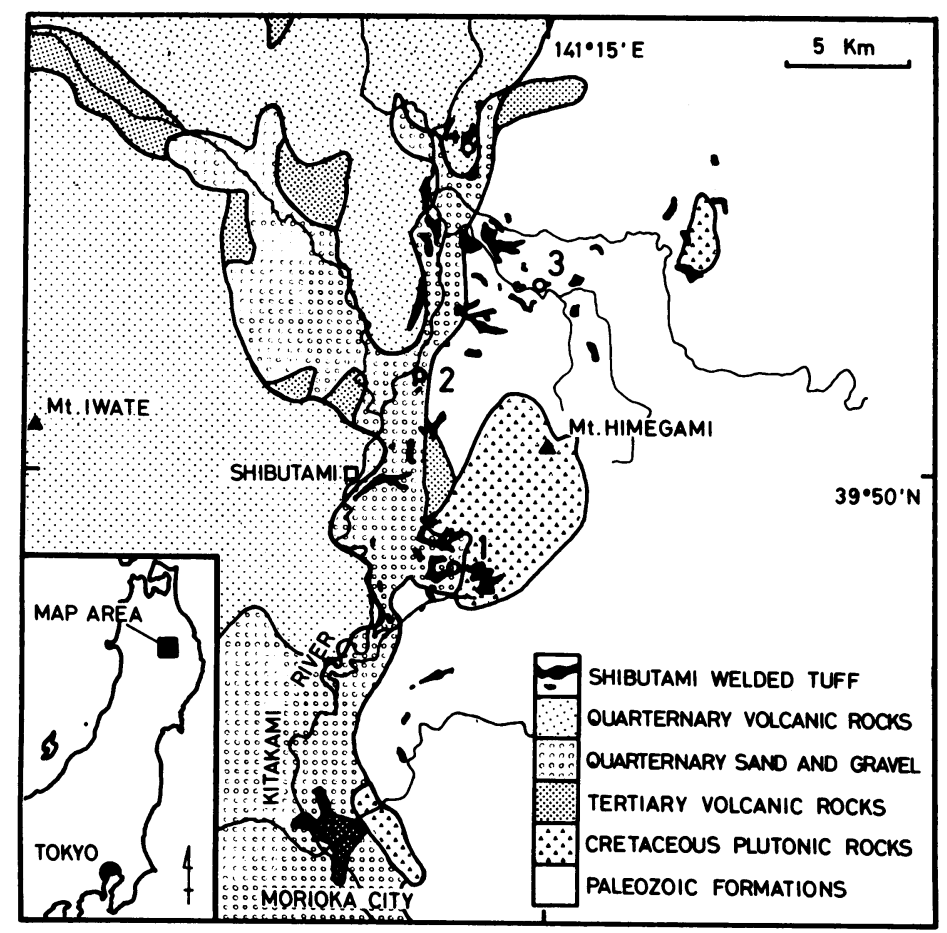

Fig. 1. Geological map of Shibutami and vicinity, compiled from the geological map of Japan by Geological SUR VEY OF JAPAN (1978) and the distribution map of the Shibutami welded tuff by TACHIBANA (1977).

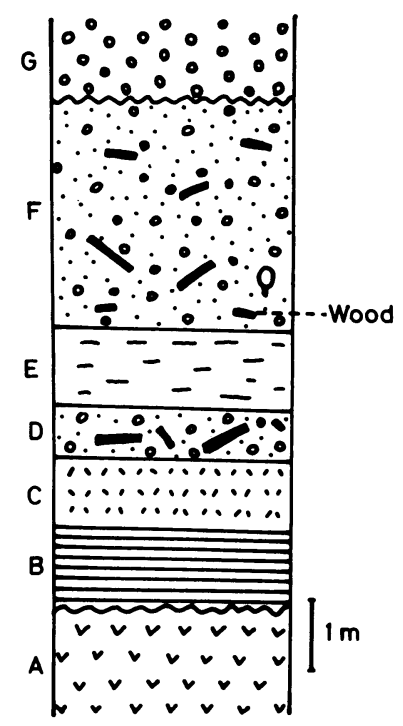

Fig. 2. One of the geological evidences showing the young age of the Shibutami welded tuff (Tachibana, 1977). Explanation is given in the text. 

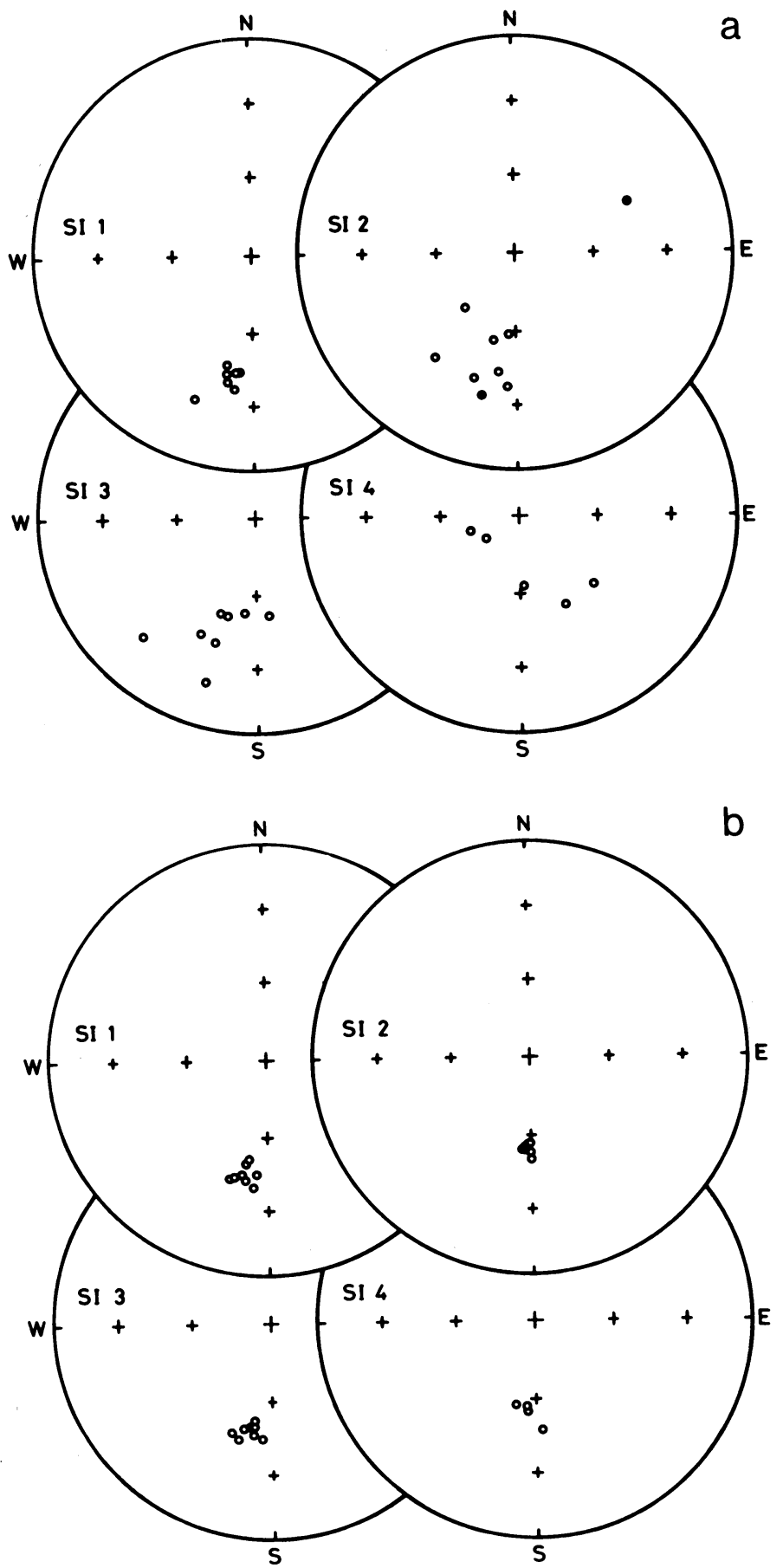

Fig. 3. NRM directions of the Shibutami welded tuff (a) and the directions of the stable remanent magnetization after cleaning in a peak field of $150 \mathrm{Oe}(\mathrm{b})$ plotted on equal area projection net. 
Table 1. Paleodirections of the Shibutami welded tuff.

\begin{tabular}{|c|c|c|c|c|c|c|c|c|}
\hline Site & LAT & LON & $N$ & $I$ & $D$ & $\alpha_{95}$ & \multicolumn{2}{|c|}{ VGP } \\
\hline SI 1 & $39.8^{\circ} \mathrm{N}$ & $141.2^{\circ} \mathrm{E}$ & 8 & $-44.9^{\circ}$ & $190.6^{\circ} \mathrm{E}$ & $3.2^{\circ}$ & & \\
\hline SI 2 & 39.9 & 141.2 & 7 & -54.3 & 182.0 & 1.9 & & \\
\hline SI 3 & 39.9 & 141.3 & 8 & -47.2 & 192.0 & 3.0 & & \\
\hline SI 4 & 40.0 & 141.2 & 5 & -55.3 & 183.8 & 5.1 & & \\
\hline Mean & & & & -50.5 & 187.5 & 6.8 & $79.4^{\circ} \mathrm{S}$ & $104.0^{\circ} \mathrm{E}$ \\
\hline
\end{tabular}

LAT, LON: Latitude and longitude of the sampling sites, $N$ : Numbers of specimens, $I$ : Inclination, $D$ : Declination, $\alpha_{95}$ : Circle of confidence, VGP: Virtual geomagnetic pole.

soft secondary component which is aligned to the present day geomagnetic field direction (IRVING, 1968). The large median demagnetizing fields (MDF) of 500 and 800 Oe indicate that the primary NRM is quite stable in these samples. All the other specimens were demagnetized by a peak field of $150 \mathrm{Oe}$ which was enough to remove most of the secondary components, and the results are shown in Fig. 3 and in Table 1. As shown in this figure, good convergence of NRM directions was obtained for all the four sites after the magnetic cleaning.

There is no doubt that the geomagnetic field was reversed in this area when this welded tuff was deposited. Geomagnetic reversals and excursions like this are reported by many authors in various areas of the world for the age range of 10,000-50,000 years B.P. summarised by VEROSUB and BANERJEE (1977). The most known is the Laschamp event found by Bonhommet (1970) at Laschamp, in the Chaine des Puys in France. The data of the Laschamp event is not yet dated precisely. The reversed lava flow was firstly dated younger than 20,000 years B.P. on the basis of $\mathrm{K}$-Ar dating but stratigraphically older than a nearby lava flow of 8,730 years B.P. of ${ }^{14} \mathrm{C}$ date (BONHOMMET and ZäHRINGER, 1969). This date of 20,000 years B.P. is not precise because it shows only the upper limit and twelve upper limits obtained by K-Ar method show large scatter. Recently redated K-Ar ages by HALL and YORK (1978) range between 35,000 and 60,000 years B.P., and an age of 39,000 years B.P. dated by ${ }^{230} \mathrm{Th} /{ }^{238} \mathrm{U}$ method and 41,000 years B.P. of thermoluminescence age were reported by ConDOMINES (1978). As the several reported ages of the Laschamp event are inconsistent, we only think here that the date of the event may be around 30,000 years B.P. Other well known excursions are Gothenburg excursion (about 13,000 years B.P., MöRnER et al., 1971), Mono Lake excursion (24,000-25,000 years B.P., Denham and Cox, 1971; LiddicoAt and Coe, 1979), Lake Mungo excursion (26,000-30,000 years B.P., BarbetTi and McElhinNy, 1976) and so on. In Japan, an excursion at 18,000 years B.P. found in the sediment core from the Lake Biwa was reported by NAKAJIMA et al. (1973) and YASKAWA et al. (1973). We have no intention of identifying these excursions, but the Shibutami geomagnetic reversal may correspond to one of these excursions.

It is of great interest to study the geomagnetic intensity during the excursion. Five specimens selected from all the samples were subjected to the Thellier's double heating paleointensity experiment performed in nitrogen atmosphere. The NRM's of these 


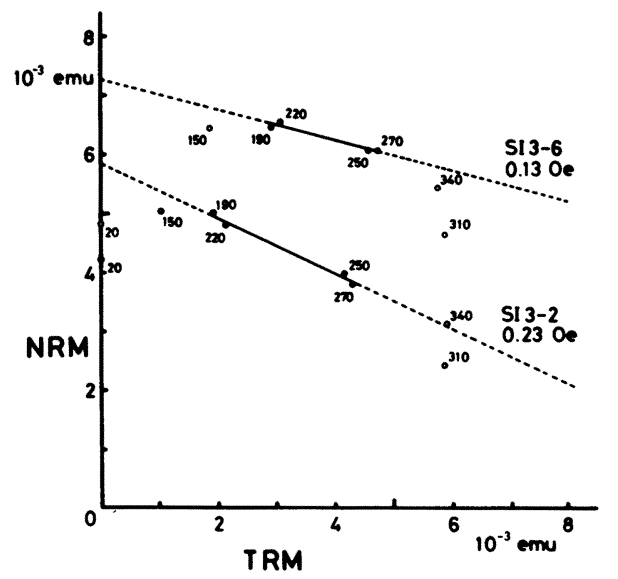

Fig. 4. Two successful results of the paleointensity experiment by the Thellier's double heating method. Small paleointensities of 0.23 and 0.13 Oe were obtained from the four points corresponding to the temperature range of $190^{\circ} \mathrm{C}$ to $270^{\circ} \mathrm{C}$.

samples were not stable for thermal demagnetization, and only two of five specimens were successful in the experiment with a low reliabilities. Figure 4 shows the NRM-TRM diagrams (Arai diagram; NAGATA et al., 1963), and small paleointensities of 0.23 and 0.13 Oe were obtained if we took the four linear points from 190 to $270^{\circ} \mathrm{C}$ in the diagrams. Although the mean value of $0.2 \pm 0.1$ Oe has very large error, it can be correctly said that the geomagnetic field intensity was small when the welded tuff was deposited. It is notable that this agrees with the often reported smallness of the geomagnetic field intensity during a polarity transition (MOMOSE, 1963; LAWLEY, 1970). In spite of many paleomagnetic studies of the excursions between 10,000 and 50,000 years B.P., only one study of the paleointensity from the Lake Mungo excursion was reported by BARBETTI and MCELHinNy (1976). Correlation betwen the Shibutami geomagnetic reversal and the Lake Mungo excursion is impossible only from these paleointensity data, but it is noted that the younger period around 26,000 years B.P. of the Lake Mungo excursion is associated with the low geomagnetic field intensity.

We thank Dr. Y. Hamano, Mr. K. Kodama and the Late Mr. Y. Matsubara of Tokyo University for the help in sample collection. We also thank to Dr. Y. Ono, Dr. H. Murakami, Dr. I. Sato, and Dr. M. Joshima of Geological Survey of Japan for the use of the spinner magnetometer. We are especially grateful to Dr. M. Kono of Tokyo University for valuable discussions and refining the manuscript. This work was financially supported by the Ministry of Education (Grant No. 374116) and by Ito Science Foundation.

\section{REFERENCES}

Barbetti, M. F. and M. W. McElhinny, The lake Mungo geomagnetic excursion, Philos. Tras. R. Soc. Lond., 281, 515-542, 1976.

Bonhommet, N., Discovery of a new event in the Brunhes period at Laschamp (France), in Paleogeophysics, edited by S. K. Runcorn, 518 pp., Academic Press, London, 1970. 
Bonhommet, N. and J. Zähringer. Paleomagnetism and potassium argon age determinations of the Laschamp geomagnetic polarity event, Earth Planet. Sci. Lett., 6, 43-46, 1969.

Condomines, M., Age of the Olby-Laschamp geomagnetic polarity event, Nature, 276, 257-258, 1978.

Denham, C. R. and A. Cox, Evidence that the Laschamp polarity event did not occur 13,300-30,400 years ago, Earth Planet. Sci. Lett., 13, 181-190, 1971.

Hall, C. M. and D. YoRK, K-Ar studies of the Laschamp and Olby lava flows, EOS, 59, 388-389, 1978.

IRviNG, E., Measurement of polarity in oceanic basalt, Can. J. Earth Sci., 5, 1319-1321, 1968.

LAWLEY, E. A., The intensity of the geomagnetic field in Iceland during Neogene polarity transitions and systematic deviations, Earth Planet. Sci. Lett., 10, 145-149, 1970.

LiddicoAT, J. C. and R. S. CoE, Mono Lake geomagnetic excursion, J. Geophys. Res., 84, 261-271, 1979.

Momose, K., Studies on the variations of the earth's magnetic field during Pliocene time, Bull. Earthq. Res. Inst., 41, 487-534, 1963.

Mörner, N. A., J. P. Lanser, and J. HosPers, Late Weichselian paleomagnetic reversal, Nature Phys. Sci., 234, 173-174, 1971.

Nagata, T., Y. Arai, and K. Momose, Secular variation of the geomagnetic total force during the last 5,000 years, J. Geophys. Res., 68, 5277-5281, 1963.

Nakajima, T., K. Yaskawa, N. Natsuhara, N. Kawai, and S. Horie, Very short-period geomagnetic excursion 18,000 yr B.P., Nature Phys. Sci., 244, 8-10, 1973.

TACHibana, K., ${ }^{14} \mathrm{C}$ ages and geomagnetic reversals of the Shibutami welded tuff bed in the northern part of Morioka, Ann. Rep. Fac. Educ., Iwate Univ., 37, 9-25, 1977 (in Japanese).

Verosub, K: L. and S. K. Banerjee, Geomagnetic excursions and their paleomagnetic record, Rev. Geophys. Space Phys., 15, 145-155, 1977.

Yaskawa, K., T. Nakajima, N. Kawai, M. Toril, N. Natsuhara, and S. Horie, Paleomagnetism of a core from Lake Biwa (I), J. Geomag. Geoelectr., 25, 447-474, 1973. 